\title{
RELATIONSHIP BETWEEN INDIVIDUAL ATTRIBUTIONAL STYLE, SELF-ESTEEM, LOCUS OF CONTROL AND ACADEMIC ACHIEVEMENT OF VYTAUTAS MAGNUS UNIVERSITY STUDENTS
}

\author{
Laima Ruibytè \\ Mykolas Romeris University, Kaunas, Lithuania
}

\begin{abstract}
Laima Ruibytė. Doctor of Social Sciences, Assoc. Professor, Head of the Department of Humanities, Kaunas Faculty of Police, Mykolas Romeris University. Research interests: factors and peculiarities of the formation of social stereotypes and attitudes; psychological aspects of athletes' activities.
\end{abstract}

\begin{abstract}
This study was aimed to investigate the link between students'self-esteem, individual attribution style, locus of control and academic achievement for better understanding of students'learning and adaptation problems.

The main purpose of the research was to examine the relationship between the individual attributional style, locus of control and self-esteem, analyse, to analyze how these features of personality were related to future aspirations and how the afore-mentioned features were reflected in the academic activity of students. The tasks set for the analysis of the survey data were as follows: to identify specific features of self-esteem, locus of control and attributional style and their interrelation, analyse the link between self-esteem and future aspirations of the individual, and identify the link of self-esteem and locus of control with academic grade.

Participants were 200 Vytautas Magnus University students (59 males and 141 females). For the purpose of survey we used the questionnaire of 52 items constructed by us which comprised three blocks: self-esteem, attributional style and locus of control. Self-esteem of students was measured using Rosenberg (RVS) self-esteem scale (10 statements). To determine specific features of attribution (15 questions) we used the respondents'opinion regarding their colloquium grade (two questions) and interpretation of reasons for getting such grade (eight questions) based on B. Weiner's model (Weiner, 1985). One question reflected the student's expectations before the exam and one was intended to determine the student's attribution style in foreseeing the factors predefining the future result. The scale of the locus of control (27 statements) was worked out on the basis of the Subjective Control Level (YCK) survey methods developed by the Scientific Research Institute of Bechterev and the Occupational Stress Indicator (OSI) Methods created according to the Dutch version of Spanningseter.
\end{abstract}

The main conclusions are:

1. The survey results confirmed the interrelationship between self-esteem and internality (externality) — students with higher level of self-esteem have higher internality score.

2. Low and high self-esteem students explain their success using different attributional style. Boys and girls with higher level of self-esteem attached greater importance to their internal and stable features and valued unstable external factors less than low self-esteem students.

3. In addition to different interpretation of current events, students-internals and externals also had different perception of their future result. Externals more than internals were inclined to believe that their examination grade would be predetermined by external causes.

4. Subjective locus of control was linked to results and achievements of individual activities. Girl-students with relatively higher internality had better results in academic activities, i.e. their received grade than girl-students externals. The data on boys did not reflect statistically reliable link between internality and received grade.

5. Level of internality keeps growing with age. Particularly distinct is the dependence of internality upon the year of studies in which the respondents are studying. Senior girls and boys manifest higher level of internality.

It seems that students' attributions, locus of control, self-esteem and academic achievement are strongly connected and thus they have to be applied for effective teaching.

Keywords: individual attribution style, self-esteem, locus of control, academic achievement.

\section{INTRODUCTION}

$\mathrm{T}$ The subjects of self-esteem and causal attribution are among the most topical areas of survey of personality and social psychology. These investigations are of high practical value as they facilitate the understanding of those personality dimensions which are important for the well-being of the individual and his adaptation in the surrounding world.

Numerous investigations confirm that the link between self-esteem, individual attributional style and locus of control exists and that such link has considerable influence on the self-esteem, 
motivation and success of activities of the individual (Forg, 1998; Ross, Maurice, 2002; Valle et al., 2003; Trautwein et al., 2006). Perception of success in the academic activity is an important factor predetermining self-esteem of teenagers and students (Kearney-Cooke, 1999). Studies of university students have shown that academic results of students with higher self-esteem are better (Kearney-Cooke, 1999; Trautwein et al., 2006).

At the same time attempts are made to find ways how to achieve the optimal harmony of these specific features of personality, how to change undesirable responses of the individual to failure or problems he faces. One of such methods investigated more widely is attributional style correction in the fields of education and health care (Peterson, Barret, 2000; Haynes et al., 2006).

Material of surveys on the relationship between the causal attribution and self-esteem in Lithuania is spare (Bistrickas, 1984; Bagdonas, Pociūtè, 1988), therefore our survey aims at examining the link between the attributional style of students and such features of personality as self-esteem and subjective locus of control, which might contribute to better understanding of learning and adaptation problems of students.

The main purpose of the conducted survey was to analyse the link between the individual attributional style, locus of control and self-esteem, to examine how these features of personality are related with future aspirations and how the aforementioned features are reflected in the academic activity of students. The principal aims of this research were: to identify specific features of selfesteem, locus of control and attributional style and their interrelation, analyse the relationship between self-esteem and future aspirations of the individual and identify the relationship between self-esteem, locus of control and academic grades.

\section{METHOD}

Participants. Two hundred students (59 males and 141 females) from Vytautas Magnus University participated in the survey. When forming the sample attempts were made to include students of all faculties of the university. The students were randomly selected from the second $(40.0 \%)$, the third $(30.5 \%)$ and the fourth $(23.5 \%)$ years of studies.

Instruments. For the purpose of survey we used the questionnaire of 52 items prepared by us which comprised three blocks: self-esteem, attributional style and locus of control. The self-esteem of students was measured using Rosenberg's 10 statements Self-esteem Scale (Rosenberg, 1986). Internal consistency of the scale was 0.82 .

To determine the specific features of attribution (15 questions) we used the respondents' opinion regarding their exam grades (two questions) and interpretation of reasons for getting such grades (eight questions) based on Weiner's model (Weiner, 1985). One question reflected the student's expectations before the exam and one was intended to determine the student's attributional style in foreseeing the factors predefining their future result. These potential factors, likewise the reasons for the actually obtained result were split into four categories based on the above-mentioned Weiner's model. As there is a tendency of underestimating the importance of the task in case of failure, the survey questionnaire was supplemented with questions enabling the student to assess the importance of this subject (two questions).

The scale of the locus of control (27 statements) has been worked out on the basis of the Subjective Control Level (УCK) survey methods developed by the Scientific Research Institute of Bechterev (Кондаков, Нилопец, 1995) and the Occupational Stress Indicator (OSI) Methods created according to the Dutch version of Spanningseter (Lyne et al., 2000). As neither of the aforementioned methods taken separately could fully satisfy the objectives of the survey and suit the population under survey, these methods have been aggregated, modified and adapted in order to conduct this survey (Cronbach's alpha coefficient was 0.79 ). The data obtained were processed and analysed using SPSS 8.0 package (the survey and data processing was carried out with the assistance of Ala Bacinina).

\section{RESULTS}

Analysing the interdependence between selfesteem and locus of control among male students, Pearson's correlation index reflected the statically significant link of 0.483 strength $(\mathrm{p}<0.05)$. In case of female students the correlation index was slightly higher, which might be explained by the larger number of females who participated in the survey (statistics of Pearson's criterion is 0.485 , $\mathrm{p}<0.05)$.

In addition, the results of the scale of the locus of control were broken down into three groups:

1) higher level of externality (102 scores and less); 


\begin{tabular}{|c|c|c|c|c|c|c|}
\hline Self-esteem & \begin{tabular}{|l}
$\begin{array}{l}\text { Locus of } \\
\text { control }\end{array}$ \\
\end{tabular} & $\begin{array}{l}\text { Number of res- } \\
\text { pondents }(\mathrm{N})\end{array}$ & \begin{tabular}{|l} 
Medium \\
range
\end{tabular} & Chi-Square & df & Asymp. Sig \\
\hline \multirow[t]{4}{*}{ Males } & External & 18 & 23.17 & \multirow[t]{4}{*}{6.156} & \multirow[t]{4}{*}{2} & \multirow[t]{4}{*}{$0.046^{*}$} \\
\hline & Medium & 14 & 27.75 & & & \\
\hline & Internal & 27 & 35.75 & & & \\
\hline & Total & 59 & & & & \\
\hline \multirow[t]{4}{*}{ Females } & Externals & 50 & 50.33 & \multirow[t]{4}{*}{23.384} & \multirow[t]{4}{*}{2} & \multirow[t]{4}{*}{$0.000 *$} \\
\hline & Medium & 51 & 75.38 & & & \\
\hline & Internals & 40 & 91.25 & & & \\
\hline & Total & 141 & & & & \\
\hline
\end{tabular}

Table 1. The differences between self-esteem and locus of control of males and females

\begin{tabular}{|c|c|c|c|c|c|c|c|}
\hline \multirow{2}{*}{ Self-esteem } & \multirow{2}{*}{$\begin{array}{l}\text { Locus of } \\
\text { control }\end{array}$} & \multirow{2}{*}{$\mathrm{N}$} & \multirow{2}{*}{ Mean } & \multirow{2}{*}{ SD } & \multicolumn{3}{|c|}{ t-test for Equality of Means } \\
\hline & & & & & $\mathrm{t}$ & df & Sig. (2-tailed) \\
\hline \multirow[t]{2}{*}{ Males } & Externals & 18 & 28.11 & 3.82 & \multirow[b]{2}{*}{-2.639} & \multirow[b]{2}{*}{43} & \multirow[b]{2}{*}{$0.012 *$} \\
\hline & Internals & 27 & 30.89 & 3.20 & & & \\
\hline \multirow[t]{2}{*}{ Females } & Externals & 50 & 27.16 & 4.72 & \multirow{2}{*}{-4.761} & \multirow{2}{*}{88} & \multirow{2}{*}{$0.000 *$} \\
\hline & Internals & 40 & 31.50 & 3.69 & & & \\
\hline
\end{tabular}

Note. * - statistically signifficant differences between groups determined by Kruskal-Wallis test, $\mathrm{p}<0.05$

Table 2. Differences of self-esteem of internals and externals

\begin{tabular}{|c|c|c|c|c|c|c|}
\hline Causes & Level of self-esteem & $\begin{array}{c}\begin{array}{c}\text { Number of } \\
\text { respondents } \\
(\mathrm{N})\end{array} \\
\end{array}$ & $\begin{array}{c}\text { Medium } \\
\text { range }\end{array}$ & $\begin{array}{c}\text { Mann-Whitney } \\
\text { U }\end{array}$ & $\begin{array}{l}\text { Wilcoxon } \\
\text { W }\end{array}$ & $\begin{array}{l}\text { Asymp. Sig. } \\
\text { (2-tailed) }\end{array}$ \\
\hline \multirow{2}{*}{$\begin{array}{l}\text { Internal } \\
\text { unstable } \\
\text { causes }\end{array}$} & Lower self-esteem & 27 & 37.67 & \multirow{2}{*}{414.000} & \multirow{2}{*}{1194.00} & \multirow{2}{*}{$0.024 *$} \\
\hline & Higher self-esteem & 39 & 30.62 & & & \\
\hline \multirow{2}{*}{$\begin{array}{l}\text { Internal } \\
\text { stable } \\
\text { causes }\end{array}$} & Lower self-esteem & 27 & 26.31 & \multirow{2}{*}{332.500} & \multirow{2}{*}{710.50} & \multirow{2}{*}{$0.004 *$} \\
\hline & Higher self-esteem & 39 & 38.47 & & & \\
\hline \multirow{2}{*}{$\begin{array}{l}\text { External } \\
\text { unstable } \\
\text { causes }\end{array}$} & Lower self-esteem & 28 & 37.95 & \multirow{2}{*}{435.500} & \multirow{2}{*}{1125.50} & \multirow{2}{*}{0.124} \\
\hline & Higher self-esteem & 39 & 31.17 & & & \\
\hline \multirow{2}{*}{$\begin{array}{l}\text { External } \\
\text { stable } \\
\text { causes }\end{array}$} & Lower self-esteem & 27 & 37.54 & \multirow{2}{*}{417.500} & \multirow{2}{*}{1197.50} & \multirow{2}{*}{0.078} \\
\hline & Higher self-esteem & 39 & 30.71 & & & \\
\hline
\end{tabular}

Note. $*$ - differences are signifficant, $\mathrm{p}<0.05$.

2) medium group (103-110 scores);

3) higher level of internality (111 scores and more).

The difference between self-esteem of male students and female students depending upon the group of the locus of control was statistically significant, which was also confirmed by all statistical criteria applied (Table 1). Consequently, the higher the level of internality, the higher the self-esteem.

The comparison of the internals and externals was carried out using the version of T-criterion level dispersions. Table 2 shows that the average self-esteem value of males externals in scores amounted to 28.11 , whereas the self-esteem ave- rage of internals was by 2.78 points higher. This difference was statistically significant $(p<0.05)$. Self-esteem among females in these two groups differed even more: the higher-level internality group's average was 31.50 and self-esteem in higher-level externality was by 4.34 points smaller than the average of the first group $(\mathrm{p}<0.05)$.

The analysis of self-esteem and attributional style showed that females with higher level of self-esteem in case of success attached the greatest importance to the stable internal causes (medium range $=38.48$ ) compared to low self-esteem females (medium range $=26.31$ ), whilst females with lower self-esteem in case of success were more apt 


\begin{tabular}{|c|c|c|c|c|c|c|c|c|c|c|}
\hline \multirow{9}{*}{$\begin{array}{l}\text { Table 4. Asses- } \\
\text { sment of causes } \\
\text { of success among } \\
\text { males with higher } \\
\text { and lower level of } \\
\text { self-esteem }\end{array}$} & Causes & \multicolumn{2}{|c|}{ Level of self-esteem } & \multicolumn{2}{|c|}{$\begin{array}{c}\text { Number of res- } \\
\text { pondents }(\mathrm{N})\end{array}$} & $\begin{array}{c}\text { Medium } \\
\text { range }\end{array}$ & & $\begin{array}{l}\text { ann-Whitney } \\
\text { U }\end{array}$ & $\begin{array}{c}\text { Wilcoxon } \\
\text { W }\end{array}$ & $\begin{array}{c}\text { Asymp. Sig. } \\
\text { (2-tailed) }\end{array}$ \\
\hline & Internal & \multicolumn{2}{|c|}{ Lower self-esteem } & \multicolumn{2}{|l|}{7} & 10.64 & \multirow{2}{*}{\multicolumn{2}{|c|}{46.500}} & \multirow{2}{*}{74.500} & \multirow{2}{*}{0.802} \\
\hline & $\begin{array}{l}\text { unstable } \\
\text { causes }\end{array}$ & \multicolumn{2}{|c|}{ Higher self-esteem } & \multicolumn{2}{|l|}{14} & 11.18 & & & & \\
\hline & Internal & \multicolumn{2}{|c|}{ Lower self-esteem } & \multicolumn{2}{|l|}{7} & 8.5 & \multirow{2}{*}{\multicolumn{2}{|c|}{31.500}} & \multirow{2}{*}{59.500} & \multirow{2}{*}{0.142} \\
\hline & $\begin{array}{l}\text { stable } \\
\text { causes }\end{array}$ & \multicolumn{2}{|c|}{ Higher self-esteem } & \multicolumn{2}{|l|}{14} & 12.25 & & & & \\
\hline & External & \multicolumn{2}{|c|}{ Lower self-esteem } & \multicolumn{2}{|l|}{7} & 13.21 & \multirow{2}{*}{\multicolumn{2}{|c|}{33.500}} & \multirow{2}{*}{138.500} & \multirow{2}{*}{0.213} \\
\hline & $\begin{array}{l}\text { unstable } \\
\text { causes }\end{array}$ & \multicolumn{2}{|c|}{ Higher self-esteem } & \multicolumn{2}{|l|}{14} & 9.89 & & & & \\
\hline & External & \multicolumn{2}{|c|}{ Lower self-esteem } & \multicolumn{2}{|l|}{7} & 11.79 & \multirow{2}{*}{\multicolumn{2}{|c|}{43.500}} & \multirow[b]{2}{*}{148.500} & \multirow[b]{2}{*}{0.667} \\
\hline & $\begin{array}{l}\text { stable } \\
\text { causes }\end{array}$ & \multicolumn{2}{|c|}{ Higher self-esteem } & \multicolumn{2}{|l|}{14} & 10.61 & & & & \\
\hline \multirow{7}{*}{$\begin{array}{l}\text { Table 5. Corre- } \\
\text { lation between } \\
\text { female's locus of } \\
\text { control and cau- } \\
\text { sal attribution of } \\
\text { the future results }\end{array}$} & Causes & $\begin{array}{c}\text { Locus of } \\
\text { control }\end{array}$ & $\begin{array}{l}\text { Number of } \\
\text { respondents } \\
\text { (N) }\end{array}$ & $\begin{array}{c}\text { Medium } \\
\text { range }\end{array}$ & $\begin{array}{c}\text { Mann- } \\
\text { Whitney } \\
\text { U }\end{array}$ & \multicolumn{2}{|c|}{$\begin{array}{c}\text { Wilcoxon } \\
\text { W }\end{array}$} & $\begin{array}{l}\text { Asymp. Sig. } \\
\text { (2-tailed) }\end{array}$ & $\begin{array}{c}\text { Kolmogorov- } \\
\text { Smirnov } \\
\text { Z. }\end{array}$ & $\begin{array}{c}\text { Asymp. Sig. } \\
\text { (2-tailed) }\end{array}$ \\
\hline & Internal & Externals & 48 & 48.33 & \multirow[b]{2}{*}{776.00} & & & & & \\
\hline & $\begin{array}{l}\text { unstable } \\
\text { causes }\end{array}$ & Internals & 40 & 39.90 & & 1596. & & 0.119 & 1.012 & 0.257 \\
\hline & Internal & Externals & 47 & 50.98 & & & & & & \\
\hline & $\begin{array}{l}\text { stable } \\
\text { causes }\end{array}$ & Internals & 40 & 35.80 & 612.00 & 1432. & & $0.005^{*}$ & 1.375 & $0.046^{*}$ \\
\hline & External & Externals & 46 & 32.54 & & & & & & \\
\hline & $\begin{array}{l}\text { unstable } \\
\text { causes }\end{array}$ & Internals & 40 & 56.10 & 416.00 & 1497. & & $0.000^{*}$ & 1.845 & $0.002 *$ \\
\hline $\begin{array}{l}\text { Note. } * \text { - diffe- } \\
\text { rences are signiffi- }\end{array}$ & External & Externals & 48 & 43.56 & & 1 & & 0 & 0803 & 0300 \\
\hline & causes & Internals & 40 & 45.63 & & & & & & \\
\hline
\end{tabular}

to value external unstable causes (medium range $=$ 37.95) (Table 3).

The analysis of the survey results of males (Table 4) did not reveal any statistically significant differences in interpreting the causes of success. Such results might have been predetermined by the fact that the percentage of males in the sample was rather small and due to a small number of respondents. The differences between males with high and low level of self-esteem was not so manifested as among females. The tendency of attribution of success causes among males in general corresponded to that among females: male participants with higher level of self-esteem attached greater significance to the internal and stable features (likewise in the case of women this difference was the most distinct among males with high and low level of self-esteem) and less significant to unstable external factors than students with low self-esteem.

Table 5 contains data on the relationship between the individual's locus of control and their attributional features. Externals and internals (females) statistically significantly differed in terms of their assessment of the factors predetermining the future result (higher medium range reflected small impact of the factor on the future result).

Female externals were inclined to believe that their future result would mostly depend upon external unstable causes, i.e. upon the degree of difficulty of the task or chance (good luck). Meanwhile, females-internals believed that their future result least depended upon external unstable causes. For female-internals internal stable causes were of greater importance for the future result than females-externals.

Similar results were obtained from the analysis of the differences between internals and externals among males. Table 6 shows that in case of males, however, statistically significant differences between internals and externals were observed only in the group of external unstable causes. 


\begin{tabular}{|c|c|c|c|c|c|c|c|c|c|}
\hline Causes & $\begin{array}{c}\text { Locus of } \\
\text { control }\end{array}$ & $\begin{array}{c}\text { Number of } \\
\text { respondents } \\
(\mathrm{N}) \\
\end{array}$ & $\begin{array}{c}\text { Medium } \\
\text { range }\end{array}$ & $\begin{array}{c}\text { Mann- } \\
\text { Whitney } \\
\text { U }\end{array}$ & $\begin{array}{c}\text { Wilcoxon } \\
\text { W }\end{array}$ & $\begin{array}{c}\text { Asymp. Sig. } \\
\text { (2-tailed) }\end{array}$ & \begin{tabular}{|c} 
Kolmogorov- \\
Smirnov \\
Z.
\end{tabular} & $\begin{array}{l}\text { Asymp. Sig. } \\
\text { (2-tailed) }\end{array}$ & $\begin{array}{l}\text { Table } 6 \text {. Correlati- } \\
\text { on between male's } \\
\text { locus of control } \\
\text { and causal attri- }\end{array}$ \\
\hline \multirow{2}{*}{$\begin{array}{l}\text { Internal } \\
\text { unstable } \\
\text { causes }\end{array}$} & Externals & 18 & 27.11 & \multirow{2}{*}{169.000} & \multirow{2}{*}{547.000} & \multirow{2}{*}{0.084} & \multirow{2}{*}{1.217} & \multirow{2}{*}{0.103} & $\begin{array}{l}\text { bution of the fu- } \\
\text { ture results }\end{array}$ \\
\hline & Internals & 27 & 20.26 & & & & & & \\
\hline \multirow{2}{*}{$\begin{array}{l}\text { Internal } \\
\text { stable } \\
\text { causes }\end{array}$} & Externals & 18 & 25.25 & \multirow{2}{*}{202.500} & \multirow{2}{*}{580.5000} & \multirow{2}{*}{0.344} & \multirow{2}{*}{0.609} & \multirow{2}{*}{0.853} & \\
\hline & Internals & 27 & 21.50 & & & & & & \\
\hline \multirow{2}{*}{$\begin{array}{l}\text { External } \\
\text { unstable } \\
\text { causes }\end{array}$} & Externals & 18 & 15.31 & \multirow[b]{2}{*}{104.500} & \multirow[b]{2}{*}{275.50} & \multirow[b]{2}{*}{$0.001 *$} & \multirow[b]{2}{*}{1.521} & \multirow[b]{2}{*}{$0.020 *$} & \multirow{4}{*}{$\begin{array}{l}\text { Note. } * \text { - differen- } \\
\text { ces are signifficant, } \\
p<0.05 \text {. }\end{array}$} \\
\hline & Internals & 27 & 28.13 & & & & & & \\
\hline \multirow{2}{*}{$\begin{array}{l}\text { External } \\
\text { stable } \\
\text { causes }\end{array}$} & Externals & 18 & 23.64 & \multirow{2}{*}{231.500} & \multirow{2}{*}{609.500} & \multirow{2}{*}{0.788} & \multirow{2}{*}{0.426} & \multirow{2}{*}{0.993} & \\
\hline & Internals & 27 & 22.57 & & & & & & \\
\hline
\end{tabular}

\begin{tabular}{|c|c|c|c|c|c|}
\hline & Locus of control & Grade mean & $\begin{array}{l}\text { Medium range by } \\
\text { Kruskal-Wallis test }\end{array}$ & $\begin{array}{l}\text { Asymp. Sig. } \\
\text { (2-tailed) }\end{array}$ & \multirow{4}{*}{$\begin{array}{l}\text { grades in groups } \\
\text { with different the } \\
\text { locus of control }\end{array}$} \\
\hline \multirow{3}{*}{ Females } & External & 7.78 & 57.47 & \multirow{3}{*}{$0.006^{*}$} & \\
\hline & Medium & 8.53 & 74.12 & & \\
\hline & Internal & 8.78 & 83.94 & & \\
\hline \multirow{3}{*}{ Males } & External & 7.28 & 24.11 & \multirow{3}{*}{0.251} & \multirow{3}{*}{$\begin{array}{l}\text { Note. } * \text { - diffe- } \\
\text { rences in signiffi- } \\
\text { cant, } p<0.05 \text {. }\end{array}$} \\
\hline & Medium & 8.15 & 31.81 & & \\
\hline & Internal & 8.05 & 31.98 & & \\
\hline
\end{tabular}

The analysis of the survey data showed that the locus of control among females correlated with the received grades, i.e. the grades received by females-internals were higher than that of the externals (Kendall's tau_b correlation index showed 0.217 statically significant relationship, and Spearman's rho $=0.291, p<0.05)$. Nevertheless, the data on males did not reflect any statistically significant relationship between internality and received grade. As Table 7 shows, three groups of respondents with differently manifested locus of control reflected statistically significant relationship between the grade received by females and specific features of their locus of control, but the link between the received grade and locus of control among males was not statistically significant. The average grade of females kept gradually increasing with the growing level of their internality and the differences between the average grade of these 3 groups of the locus of control were statistically significant $(\mathrm{p}<0.05)$.

Some additional results were obtained during the analysis of the interdependence between the locus of control and the year of studies of students. The survey data on females and males were analysed separately with both cases showing a positive statistically significant relationship between internality and the year of studies $(p<0.05)$. Internality grew in parallel with the year of studies at the University. Given the statistically significant difference of female and male age distributions from the normal distribution $(\mathrm{p}<0.05)$, Spearman's rho criterion was selected to determine the interrelationship. According to the results the growing level of manifestation of internality depends upon the year of studies. This link was not very strong, however, it was statistically significant (for males - Kendall's tau $\mathrm{b}=0.222$, Spearman's rho $=0.285, \mathrm{p}<0.05$; for females - Kendall's tau $b=0.257$, Spearman's rho $=0.322, \mathrm{p}<0.05)$.

\section{DISCUSSION}

The survey has shown that students (both males and females) with higher internality also have higher self-esteem. The results confirmed the facts described in the literature about the relationship between self-esteem, internality and externality (Dutton, Brown, 1997). We can state that self-esteem and internality are directly interrelated and, this interrelationship is more manifested among females. These results are similar to those obtained by A. Valle and collegues (2003) and they show that students' predisposition to feel responsible for the results of their academic behaviour (internal 
attribution) is related to positive self-image (academic self-concept), both being important conditions for the development of learning-oriented motivation (learning goals). Persistence and effort to achieve the proposed goals has in turn a positive and significant effect on academic achievement (Valle et al., 2003).

Research shows that low and high self-esteem students explain their success using different attributional style. Females with high level of self-esteem think that their success was mostly predetermined by internal stable causes, i.e. they are inclined to believe that they are clever and can concentrate. Whereas females with lowerself esteem more often explain their success by external and unstable causes, e.g., good luck or easier task. At the same time students females with lower self-esteem significantly more than those with high level of self-esteem consider their success as a result of internal unstable causes, i.e. they are inclined to relate success with their efforts and good academic attendance, rather than with their abilities. The tendency of attribution of success causes among males in general corresponds to that among females, though the result did not reveal statistically significant difference in interpreting the causes of success by male students. We can state that students with high level of self-esteem mostly use the attributional strategy of "self-serving". Explaining their success by their skills and abilities they retain selfconfidence and good opinion about themselves. Such manner of interpretation of the results of activities according to research (Dutton, Brown, 1997 ) is beneficial for the personality. In their study J. Möller and O. Köller (2000) supported the assumption that students spontaneously generate attributions to raise or at least preserve their self-esteem. Studies on attributional retraining show opportunity for enhancing students' motivation and achievement striving by changing what students think about their success and failure (Perry et al., 1993; Struthers, Perry, 1996; Haynes et al., 2006).

In addition to different interpretation of current events, students-internals and externals also have different perception of their future result. Externals are more than internals inclined to believe that their examination grade will be predetermined by external causes. Students from the group of external locus of control are more apt to think that external and unstable causes, i.e. changing environmental factors will have greater impact on the result of future activities than internal features of their own. Students-internals on the contrary think that unstable environmental factors will have less impact on the result of their future activities. Lower responsibility assumed by externals for the future result is likely to predetermine their efforts and worse future results.

This study confirms that the locus of control is related to the results and achievements of individual activities. Female students with relatively higher internality have better results in exams. Numerous authors emphasise that the locus of control is related to academic achievements. Certain authors believe that achievements of academic and other activities among people with the locus of internal control are better compared to those with external locus of control (Ross, Maurice, 2002; Valle et al., 2003). The study examined student adjustment at Vilnius University (Balaisis et al., 2004) and found the internal locus of control to be the best predictor of adjustment. Low internal locus of control was the best predictor of poor adjustment and of emotional distress.

The literature on education provides few data on the relationship between the locus of control with age and educational background, most frequently defining it as a stable feature of the personality (Bagdonas, Pociute, 1988). This survey revealed that the locus of control is statistically significantly related to the year of studies. It has shown that the locus of control is not entirely a stable feature of personality and it might be considerably influenced by university education. Subjective variation of the locus of control in relation to the year of studies might be explained by the fact that the individual maturing and acquiring education learns to assume higher responsibility for his own behaviour and begins associating the results of his activities with personal internal features rather than with external factors. Further surveys might provide greater substantiation of these assumptions.

It seems that student attributions, locus of control, self-esteem and academic achievement are strongly connected and so have to be employed for the effective teaching. Attributional retraining, reduction of maladaptive causal explanations are the way of facilitating achievement, motivation and optimally adaptive self orientations. 


\title{
REFERENCES
}

Bagdonas, A., Pociute, L. (1988). Eksternališkumo - internališkumo skalè: mokslo darbai. Psichologija, 105115 .

Balaisis, M., Dragūns, J., Miezitis, S. (2004). Students' adjustment at Vilnius University: The role of self-orientation, locus of control, social support and demographic variables. Baltic Journal of Psychology, Vol. 5, 1, 33-45.

Bistrickas, R. (1984). Atribucija ir jos tyrimo būdai. Lietuvos TSR aukštujų mokyklų mokslo darbai. Psichologija, $5,96-107$.

Dutton, K. A., Brown, J. D. (1997). Global self-esteem and specific self-views as determinants of people's reactions to success and failure. Journal of Personality and Social Psychology, 73 (1), 139-148.

Forg, J. P. (1998). On being happy and mistaken: Mood effects on the fundamental attributional error. Journal of Personality and Social Psychology, 75 (2), 198-215.

Haynes, T. L., Ruthing, J. C., Perry, R. P., Stupnisky, R. H., Hall, N. C. (2006). Reducing the academic risks of overoptimism: The longitudinal effects of attributional retraining on cognition and achievement. Research in Higher Education, 47 (7), 755-779.

Kearney-Cooke, A. (1999). Gender difference and selfesteem. The Journal of Gender-Specific Medicine, 2 (3), $46-52$.

Lyne, K. D., Barrett, P. T., Williams, Ch., Coaley, K. A. (2000). Psychometric Evaluation of the Occupational Stress Indicator. Journal of Occupational and Organizational Psychology, 73, 152-164.

Möller, J., Köller, O. (2000). Spontaneous and reactive attributions following academic acheievement. Social Psychology of Education, 4 (1), 67-86.
Perry, R. P., Hechter, F. J., Menec, V. H., Weinberg, L. E. (1993). Enhancing achievement motivation and performance in college students: An attributional retraining perspective. Research in Higher Education, 34 (6), 687-723.

Peterson, C., Barret, L. C. (2000). Explanatory style and academic performance among university freshmen. Journal of Personality and Social Psychology, 53, 603-607.

Rosenberg, M. (1986). Conceiving the Self. Krieger Publishing Company.

Ross, M. W., Maurice, C. T. The relationship between Locus of Control and Academic Level and Sex of Secondary School Students. University of Ottawa, Algonquin College. Internet link: http://www.nald.ca/fulltext/report1/REP1001.HTM, visited on 23052002.

Struthers, C. W., Perry, R. P. (1996). Attributional style, attributional retraining, and inoculation against motivational deficits. Social Psychology of Education, 1 (2), $171-187$.

Trautwein, U., Lüdtke, O., Köller, O., Baumert, J. (2006) Self-Esteem, Academic Self-Concept, and Achievement: How the Learning Environment Moderates the Dynamics of Self-Concept. Journal of Personality and Social Psichology, 90 (2), 334-349.

Valle, A., Cabanach, R. G., Núňez, J. C. et al. (2003). Cognitive, motivational, and volitional dimensions of learning: An empirical test of a hypothetical model. Research in Higher Education, 44 (5), 557-580.

Weiner, B. (1985). An attributional theory of achievement - related motivation and emotion. Psychological Review, 29, 548-573.

Кондаков, И. М., Нилопец, М. Н. (1995). Экспериментальное исследование структуры и личностного контекста локуса контроля. Психологический журнал, 1,65 .

\section{VYTAUTO DIDŽIOJO UNIVERSITETO STUDENTŲ SĖKMĖS PRIEŽASČIŲ SUVOKIMO, SAVĘS VERTINIMO, SUBJEKTYVIOS KONTROLĖS LOKUSO IR PAŽANGUMO SĄSAJOS}

\author{
Laima Ruibytè \\ Lietuvos Mykolo Romerio universitetas, Kaunas, Lietuva
}

\section{SANTRAUKA}

Straipsnyje nagrinejjamas VDU studentų atribucinio stiliaus ir tokių asmenybės savybių kaip savęs vertinimas ir subjektyvus kontrolès lokusas ryšys, norint geriau suprasti studentų mokymosi ir adaptacijos problemas.

Tyrimo tikslas - išnagrinèti individualaus atribucinio stiliaus, kontrolès lokuso ir savęs vertinimo tarpusavio ryši, ištirti, kaip šie asmenybès bruožai susiję su asmens ateities lūkesčiais ir kaip šios savybès pasireiškia studentų akademinėje veikloje. Iškelti tokie uždaviniai: nustatyti savęs vertinimo, kontrolès lokuso ir atribucinio stiliaus ypatumus, jų tarpusavio ryšị, ištirti, kaip savęs vertinimas yra susijęs su asmens ateities lūkesčiais, nustatyti savęs vertinimo ir kontrolès lokuso ryši su akademiniu įvertinimu. Tirta VDU studentu populiacija. Imtị sudaro 200 tiriamuju, iš kurių 59 vaikinai ir 141 mergina. 
Tyrimui naudotas sukonstruotas 52 punktų klausimynas, kurị sudarè trys blokai: savęs vertinimo, atribucinio stiliaus ir kontrolès lokuso. Studentų savęs vertinimas buvo matuojamas Rozenbergo (RVS) savęs vertinimo skale (10 teiginiu). Atribucijos ypatumams nustatyti (15 klausimų) naudojome tiriamuju požiūrị i kolokviumo pažymi (du klausimai) ir toki pažymį nulėmusių priežasčių interpretavimą (aštuoni klausimai) remdamiesi B. Weiner modeliu (Weiner, 1985), taip pat ịvertinome atribucinį stilių, naudojamą numatant ateities rezultatą lemiančius veiksnius (vienas klausimas), dalyko reikšmę studentui (du klausimai) ir studento lūkesčius prieš ir po kolokviumo (du klausimai). Kontrolès lokuso skalè (27 teiginiai) buvo sudaryta naudojantis V. Bechterevo mokslinių tyrimų instituto sukurta Subjektyvios kontrolès lygio (УCK) tyrimo metodika ir Occupational Stress Indicator (OSI) metodika, sukurta pagal olandišką Spanningseter versiją.

Pagrindinès tyrimo išvados:

1. Rezultatai patvirtino savęs vertinimo ir internalumo (ar eksternalumo) tarpusavio ryši — aukštesnio savęs vertinimo studentai turi aukštesni internalumo įvertinimą.

2. Žemo ir aukšto savęs vertinimo studentai savo sèkmei aiškinti naudoja skirtingą atribucini stilių. Aukštesnio savęs vertinimo vaikinai ir merginos didesnę reikšmę teikia savo vidinèms bei stabilioms savybėms, mažesnę negu žemos savivertès studentai - nestabiliems išorės veiksniams.

3. Studentai internalai ir eksternalai skiriasi ne tik tuo, kaip jie interpretuoja dabarties ivvykius, bet ir tuo, kaip mato savo ateities rezultatą. Eksternalai labiau nei internalai linkę tikèti, kad jų egzamino pažymi lems išorinès priežastys.

4. Subjektyvus kontrolès lokusas yra susijęs su asmens veiklos rezultatais ir pasiekimais. Studenčių, kurių internalumas yra sąlygiškai didesnis, veiklos rezultatai, t. y. gautas ịvertinimas, taip pat geresnis negu studenčių eksternalių. Vaikinų duomenys nerodo statistiškai patikimo ryšio tarp internalumo ir gaunamo pažymio.

5. Nustatyta reikšminga internalumo priklausomybė nuo kurso, kuriame mokosi tiriamieji. Ir merginu, ir vaikinų studentų internalumas tuo didesnis, kuo aukštesniame kurse jie mokosi.

Išvados rodo, kad VDU studentų savęs vertinimas, individualus atribucinis stilius, kontrolès lokusas ir akademinis įvertinimas yra glaudžiai susiję, todèl galima teigti, kad į šiuos veiksnius turi būti atsižvelgta organizuojant studentų mokomają ir ugdomają veiklą.

Raktažodžiai: individualus atribucinis stilius, savęs vertinimas, kontrolès lokusas, akademinis pažangumas. 